articles published elsewhere by Havelock Ellis, Julian Huxley, Norman Himes and others, and includes several pages of abstracts and reviews of books. In the second number there is an excellent article by Norman Himes on contraceptive technique in Islam and Europe in the Middle Ages. The articles so far published indicate the scope of the journal and the quality of its contributors. It promises well, and should receive a welcome from all who are interested in those problems which arise from the relation of male to female and of parent to offspring. The price of a volume is $18 s$., and the address of the managing editor is Kodak House, Hornby Road, Bombay. Surely it is a matter of profound significance that such a journal should have had its origin in India, particularly when it is learned that, associated with the journal, there is a eugenic clinic. It would seem that this journal intends to deal frankly and scientifically with a number of topics that are not usually encountered in the ordinary medical journals.

\section{Recent Acquisitions at the British Museum (Natural History)}

THE Zoological Department has received, as a donation from His Excellency the Governor of Sierra Leone, the skull and tusks of a young specimen of the forest elephant, from the Gola Forest, Sierra Leone. This specimen is of exceptional importance as it is accompanied by two complete tusks which are in every way similar to the tusks hitherto accepted as belonging to the so-called 'dwarf' elephant. The skull and teeth of this specimen prove it to be quite a young individual and therefore it is reasonable to conclude that the so-called 'dwarf' elephant ivory is merely the ivory of young elephants. 135 mammals, 144 birds, 9 reptiles, and 500 fishes from Ashanti have been collected for the Museum by Mr. Willoughby P. Lowe and Miss Waldron, and about 200 birds collected in southern Asia Minor by Mr. Charles Bird have been purchased. The important collection of British Lepidoptera formed by the late Robert Adkin, who died at Eastbourne on May 21, has been bequeathed to the Department of Entomology. This collection consists, at an estimate, of about 50,000 specimens, and embraces the microlepidoptera as well as the larger kinds to which most collections are confined. The Trustees approved the purchase for the Department of Geology of an important collection. of some two thousand Australian fossils, including fishes, representatives of most of the invertebrate groups, and plants. It is particularly valuable on account of the large number of Permian and Triassic insects, including more than 100 types, which it contains. An interesting and valuable gold nugget from Morro Velho, Minas Geraes, Brazil has been bequeathed to the Department of Mineralogy, by the late Mrs. M. A. Bushnan, of Kow. The nugget, which weighs $119 \cdot 3$ grams, or nearly 4 ounces troy, consists entirely of native gold, all the original quartz having been removed, leaving a cellular structure. Among the purchases may be mentioned : a splendid scissor-cut yellow scapolite, weighing $12 \cdot 3$ carats. The rough stone was from Serra da Chibita, Minas
Geraes, Brazil. Scapolite of gem quality is not common, and this specimen is larger and of better colour than any other in the National Collection.

\section{A Disease-Resistant Red Currant}

A short note issued by Science Service of Washington, D.C., announces the discovery by Dr. G. G. Hahn of a new variety of red currant resistant to the uredo- and teleuto-spore stages of Cronartium ribicola, the white pine blister rust fungus. This organism is hetercecious, spending its life-history on two distinct host plants. Currants and gooseberries are the summer hosts, whilst the æcidial stage is spent upon white pine (Pinus strobus) in the winter. Many districts in America regard the white pine as their principal source of wealth, and so both wild and cultivated currants and gooseberries were eradicated completely. This caused much grief and expense to gardeners, but removed the necessary summer hosts of the fungus, and effectively con. trolled the disease on white pine. The now diseaseresistant red currant is known as 'Viking' ; it provides fruit of good quality, and promises to withstand drought as well as to resist disease.

\section{Centralisation of Scientific Publication}

IN an address on "The Dissemination of Science" before the American Association for the Advancement of Science at Minneapolis on June 26, Mr. Watson Davis, director of Science Service, reiterated a plea for the co-operative centralisation of some scientific publication functions in a Scientific Information Institute. It was suggested that manuscripts which could not be published promptly or in full should be sent to the Institute and prepared by typing or otherwise for photographic publication. The existence of the paper or monograph would be made known through the publication of the abstract in the scientific journal, and the paper could be obtained on request, each copy being made to order. The same system could be utilised for supplying to members the scientific papers delivered at a meeting. The photographic procedure might also be utilised for loans between libraries. In regard to bibliography, Mr. Davis suggested the operation by the Scientific Information Institute of a bibliographical file and production service to absorb existing bibliographical schemes in all branches of science and provide bibliographical material in fields of science which are at present not easily accessible. A fund of approximately 20,000 dollars would enable these projects to be initiated.

\section{The National Central Library}

THE nineteenth annual report of the National Central Library, Malet Place, London, W.C.1, directs attention to the difficult financial problems which at present confront the Committee. These are due partly to the inadequacy of its income to meet the growing demands made upon the Library and partly to the termination of the annual grants received from the Carnegie Trustees, from whom a final grant of $£ 4,000$ has now been received. The annual grant 